U.S. DEPARTMENT OF THE INTERIOR

U.S. GEOLOGICAL SURVEY

\title{
GEOPHYSICS OF THE SAN BERNARDINO NATIONAL FOREST, SOUTHERN CALIFORNIA
}

By

D.A. Ponce ${ }^{1}$, W.F. Hanna ${ }^{2}$, Marguerite Kingston ${ }^{2}$,

S.L. Simpson ${ }^{3}$, and S.L. Snyder ${ }^{2}$

GEOLOGICAL SURVEY OPEN-FILE REPORT 96-654

${ }^{1}$ U.S. Geological Survey, Menlo Park, Californnia

${ }^{2}$ U.S. Geological Survey, Reston, Virginia

${ }^{3}$ U.S. Geological Survey, Denver, Colorado 


\section{CONTENTS}

Page

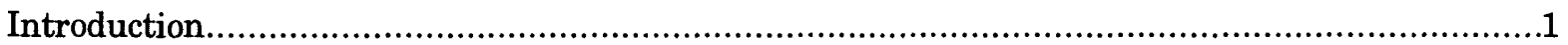

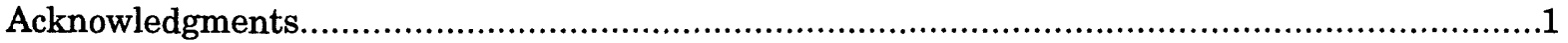

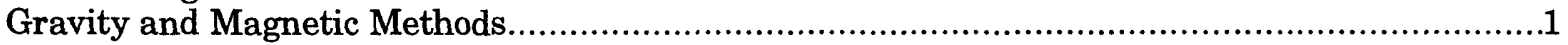

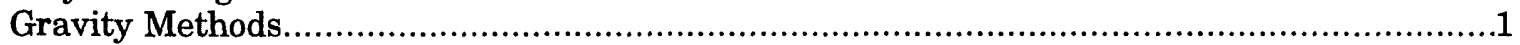

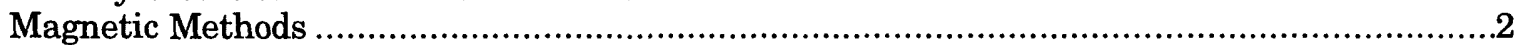

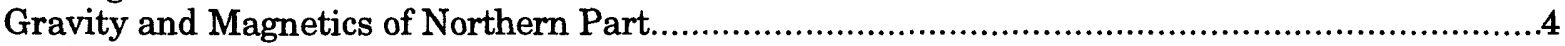

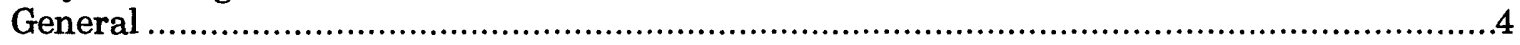

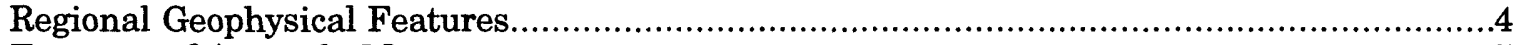

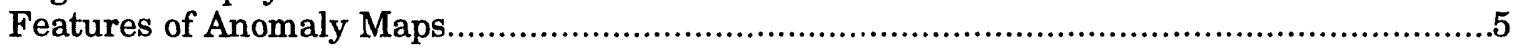

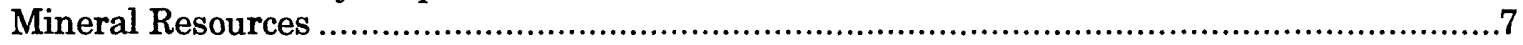

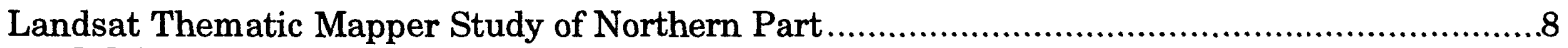

TM Characteristics and Data Processing.......................................................................

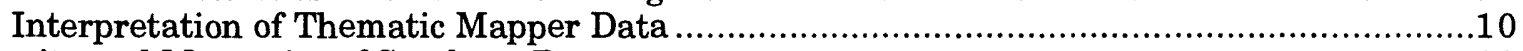

Gravity and Magnetics of Southern Part....................................................................12

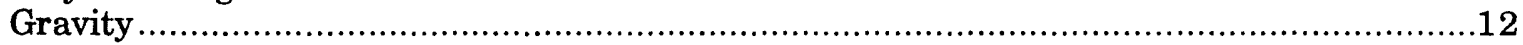

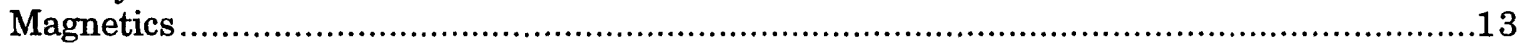

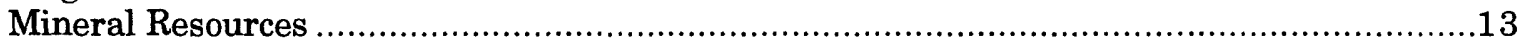

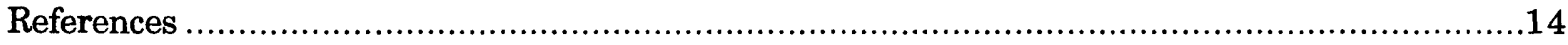

\section{ILLUSTRATIONS}

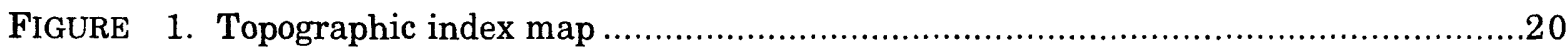

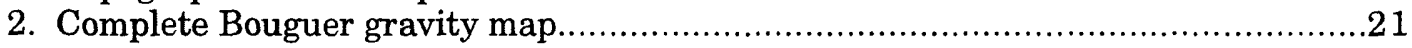

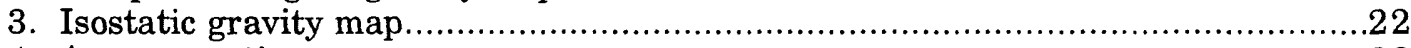

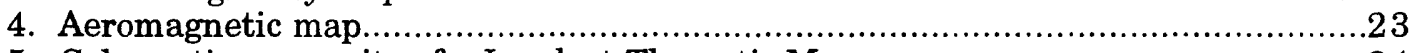

5. Color-ratio composite of a Landsat Thematic Mapper scene ............................24

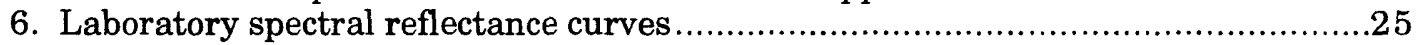

\section{TABLES}

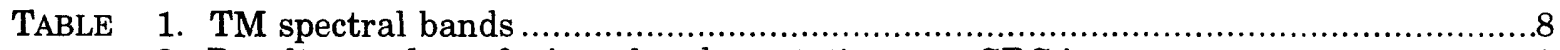

2. Resultant colors of mineral and vegetation on a CRC image ............................. 


\section{INTRODUCTION}

The San Bernardino National Forest (SBNF) is geographically separated by lat $34^{\circ} \mathrm{N}$. into northern and southern parts, each of which is discussed separately because they are geophysically different and are located in different physiographic provinces of California (Jahns, 1954). In addition, a remote sensing image is available only for the northern part. The northern part of the SBNF lies within the Transverse Ranges province and includes parts of the San Gabriel and San Bernardino Mountains while the southern part is within the Peninsular Ranges province and includes parts of the San Jacinto and Santa Rosa Mountains. W.F. Hanna and S.L. Snyder discuss gravity and magnetic data and Marguerite Kingston and S.L. Simpson discuss remote sensing data for the northern part of the SBNF; D.A. Ponce discusses gravity and magnetic data for the southern part of the SBNF.

Typically, gravity and magnetic data and their derivative products reflect lateral changes in rock density or magnetic properties and thus can yield information on subsurface geologic structures that may be related to possible mineral resource potential. In addition, magnetic data can sometimes indicate areas of mineralization or rock alteration directly. Remote sensing data, in this case Landsat Thematic Mapper (TM) data, can be used as a guide for mapping various lithologic units. Three spectral bands were used in this study to enhance color differences of the earth's surface to detect various mineral assemblages and thus may be utilized to help assess mineral resource potential.

\section{ACKNOWLEDGMENTS}

V.E. Langenheim, E.A. Dixon, and N. Kitchen assisted in collection and reduction of gravity and physical property data.

\section{GRAVITY AND MAGNETIC METHODS}

\section{Gravity Methods}

Gravity anomalies were calculated using standard corrections (Dobrin and Savit, 1988) including terrain and isostatic corrections. Data were referenced to the International Gravity Standardization Net 1971 gravity datum described by Morelli (1974) and reduced using the Geodetic Reference System 1967 formula for theoretical gravity (International Union of Geodesy and Geophysics, 1971). Anomalies were computed using a standard reduction density of $2.67 \mathrm{~g} / \mathrm{cm}^{3}$.

Terrain corrections, which remove the effect of topography, were made from the station to a radial distance of $167 \mathrm{~km}$ using a digital elevation model and a procedure by Plouff (1977). Isostatic corrections were calculated using an Airy-Heiskanen model for isostatic compensation of topographic loads (Jachens and Roberts, 1981) with an assumed sea-level crustal thickness of $25 \mathrm{~km}$, a crustal density of $2.67 \mathrm{~g} / \mathrm{cm}^{3}$, and a density contrast across the base of the crust of $0.4 \mathrm{~g} / \mathrm{cm}^{3}$. Isostatic corrections were determined to enhance geologic features of the mid- to upper-crust by removing longwavelength variations in the gravity field inversely related to regional topography. In general, isostatic corrections are insensitive to large changes in the isostatic model parameters (Jachens and Griscom, 1985).

Both complete Bouguer and isostatic gravity maps (figs. 2 and 3) were compiled for the SBNF from publicly available gravity data (Snyder and others, 1981) supplemented by data collected by Ponce and others (unpub. data, 1991). In addition, maximum horizontal gradients were derived from the isostatic gravity data (fig. 3). The locations of points of maximum horizontal gradients occur 
approximately over the edges of shallow causative features and are useful for defining the lateral extent of geologic features and for locating linear trends (Cordell and Grauch, 1985; Blakely and Simpson, 1986).

Previously published gravity data of the SBNF include a principal facts report and a complete Bouguer gravity map of the San Bernardino quadrangle (Tang and Ponce, 1982; Biehler and others, 1988), an isostatic gravity map of the Santa Ana 1:100,000-scale quadrangle by Langenheim and others (1991), an isostatic gravity map of the Palm Springs 1:100,000-scale quadrangle by Ponce and Langenheim (1992), and a complete Bouguer gravity map of the Santa Ana quadrangle was published by Biehler and others (1992).

\section{Magnetic Methods}

Aeromagnetic data north of lat $34^{\circ}$, within and surrounding the northern part of the SBNF area, were compiled from six surveys (Andreasen and others, 1964a; U.S. Geological Survey, 1979, 1981, 1982, 1987; High Life Helicopters, Inc. and Q.E.B., Inc., 1980), and data south of $34^{\circ}$, within and surrounding the southern part of the SBNF area, were compiled from five surveys (Andreasen and others, 1964a,b; U.S. Geological Survey, 1979, 1982, 1990). This patchwork of surveys is characterized by diverse flight specifications, including various flight directions, flight heights, and flight spacings. A single aeromagnetic map (fig. 4) was constructed by computationally merging the individual data sets. In general, the aeromagnetic data are too sparse or the flight-line elevation is too high to define small-scale mineral occurrences or small-scale geologic features that may be associated with potential mineral resources.

Prior to the merging process, the individual anomaly maps were first compared to one another in regions of overlap and were subsequently compared with other anomaly maps of more limited extent or lesser quality that overlap the region of our study (Youngs, 1985, 1988; Hill, 1991). After deciding on the priorities of acceptance of data and confirming that appropriate International Geomagnetic Reference Fields (Peddie, 1983) had been subtracted from original total-intensity magnetic field measurements, we proceeded to develop a grid of digital data. First, all originally analog data were digitized by assigning anomaly point values to each map location marked by the intersection of an anomaly contour line with a flight trace and by projecting and gridding this set of points at a 1-km interval. Second, all originally digital data were also gridded at this 1-km interval and registered to the same origin of coordinates. Following this gridding, each data set was analytically continued either upward or downward to simulate data acquired at a height $305 \mathrm{~m}$ $(1,000 \mathrm{ft})$ above the ground surface. Following this height adjustment, the data were merged by using a smooth splining algorithm. The resulting map, contoured at an interval of 40 nanoteslas (nT) or gammas, thus represents the equivalent of a single survey draped $305 \mathrm{~m}(1,000 \mathrm{ft})$ above topography but suffers from errors associated with the inherently inconsistent flight specifications of individual surveys and errors propagated by the merging process. In general, we consider the resulting map to be sufficiently accurate to delineate most anomalous features having an areal extent of about $8 \mathrm{~km}^{2}\left(3 \mathrm{mi}^{2}\right)$ or larger.

The development of a coherent grid of digital anomaly values also provides an opportunity to efficiently compute derivative products as an aid to the display or interpretation of the anomaly data. As an example of such a derivative product, a map showing boundary points that tend to delineate the outlines of magnetic bodies has been produced (fig. 4). This map of boundary points was developed by transforming the merged magnetic anomalies to pseudogravity anomalies by use of Poisson's relation (Lourenco, 1972; Baranov, 1975; Hildenbrand, 1983; Blakely and Simpson, 1986; Grauch and Cordell, 1987). This transformation achieves 3 purposes: (1) It shifts anomaly centers directly over their causative sources, effectively correcting for the magnetic inclination of the Earth's magnetic field (which affects induced, but not remanent, magnetization), just as does the reduced-to-pole transformation; (2) unlike the reduced-to-pole transformation, it converts magnetic 
anomalies to equivalent gravity anomalies on the assumptions that causative sources generate both types of anomalies and that the average ratio of density to magnetization is known (thus, locations of pseudogravity anomalies can be compared directly to locations of measured gravity anomalies to determine which causative sources actually generate both types of anomalies); and (3) it offers a mathematically noise-reduced function from which magnitudes of horizontal gradients can be computed, thereby areally highlighting regions where causative sources have relatively steep boundaries in the shallow subsurface. The boundary points therefore represent points of local maxima of the magnitude of pseudogravity horizontal gradient and, if connected, tend to outline regions of anomalous magnetization. 


\section{GRAVITY AND MAGNETICS OF NORTHERN PART}

\section{General}

The northern part of the SBNF (fig. 1) is located within the Transverse Ranges province, in contrast to the southern part of the SBNF, which is located in the Peninsular Ranges province (Bailey, 1966, fig. 1). The northern SBNF area overlaps the southeastern third of the San Gabriel Mountains and the northwestern two-thirds of the San Bernardino Mountains. The southeastern third of the San Gabriel Mountains is underlain by large tracts of metamorphic, igneous, and sedimentary rocks, and mylonite zones, many of unknown age. Included in these rocks are the Pelona Schist, undifferentiated gneiss, high-grade metamorphic rocks, metasedimentary rocks, "Black Belt" Mylonite unit, and limestone and marble, all of unknown age, as well as Jurassic quartz diorite, Cretaceous and Tertiary granitic rocks, Miocene and Pliocene volcanic and sedimentary rocks, and Holocene sedimentary deposits (Bortugno and Spittler, 1986). The San Gabriel mountains west of the SBNF area, between long $118^{\circ} 10^{\prime} \mathrm{W}$. and $118^{\circ} 25^{\prime} \mathrm{W}$., contains an anorthosite complex having significant amounts of gabbro and norite that have been studied geophysically (Cummings and Regan, 1976). The northwestern two-thirds of the San Bernardino Mountains is underlain by Precambrian gneissic and amphibolitic basement; overlying late Precambrian and Paleozoic metasedimentary rocks, which contain in stratigraphic succession quartzite, dolomite, and limestone; Mesozoic intrusive rocks, including hornblende monzonite, granitic cataclaste, hornblende gabbro, diorite dikes and sills, quartz latite porphyry dikes, biotite quartz monzonite plutons, migmatized rocks, mylonite, and felsite dikes; and Quaternary deposits (Morton and others, 1980; Matti and others, 1987; Brown, 1991).

In both the San Gabriel and San Bernardino Mountains several major tectonic events of Mesozoic and Cenozoic age have been recognized (Allen and Meisling, 1983; Hauksson and others, 1988; Tennyson, 1989; Namson and Davis, 1988, 1989a,b; Weldon and Humphreys, 1989; Yeats and Huftile, 1989; Wallace, 1990; Brown, 1991). For example, Mesozoic events included complex multiphase folding and thrust faulting, thermal and regional metamorphism, and extensive igneous intrusion. Cenozoic events included low- and high-angle faulting, gentle folding, and significant volcanism. Major Neogene rotations of crustal blocks have been recognized in this part of southern California on the basis of paleomagnetic studies of remanent magnetization declinations (Luyendyk and others, 1980). Both mountain ranges were formed by uplift and were partially eroded during the Cenozoic and the major province boundary marked by the north branch of the San Andreas fault, which slices between the San Gabriel and San Bernardino Mountains, was formed during the Cenozoic. Some faults in and near the study area have been and are currently active, posing earthquake risks (Ellsworth, 1990).

\section{Regional Geophysical Features}

Reconnaissance gravity and magnetic surveys and regional compilations of anomaly data (see, for example, Mabey, 1960; Hanna and others, 1972; Blake and others, 1978; Oliver and others, 1980; Bond and Zietz, 1987; Griscom and Jachens, 1990; and Roberts and others, 1990) within or surrounding the SBNF study area revealed that magnetic and gravity highs in this area are usually associated with specific types of metamorphic rocks and intermediate to mafic igneous rocks and that gravity lows are commonly associated with felsic igneous rocks and with basin fill deposits and alluvium (Jennings, 1977).

Of relevance to gravity studies, the San Bernardino Mountains are the highest of the Transverse Ranges and crest at Mount San Gorgonio (fig. 1) at about 3,500 m (11,500 ft), the highest point in southern California. The adjacent San Gabriel Mountains crest at Mount San Antonio (fig. 1) at a little more than $3,050 \mathrm{~m}(10,000 \mathrm{ft})$, with the average elevation of these mountains being about 305 $\mathrm{m}(1,000 \mathrm{ft})$ less than the average elevation of the San Bernardino Mountains. Studies of the ratio 
between the change in Bouguer gravity anomalies to change in regional elevation (Oliver, 1980) indicate that both ranges are in approximate regional isostatic balance. Seismic data (Hadley and Kanamori, 1977) indicate that the San Gabriel Mountains are not underlain by a local compensating root; rather, the regional compensation appears to be accomplished under the southwestern part of the Mojave Desert and northern edge of the Transverse Ranges (Oliver, 1980). The regional gravity and elevation data further imply that the crust is about $3 \mathrm{~km}$ thicker under the northern part of the San Bernardino Mountains than under most of the San Gabriel Mountains.

\section{Features of Anomaly Maps}

The Bouguer gravity map (fig. 2) in and surrounding the northern SBNF area (Tang and Ponce, 1982; Biehler and others, 1988) is dominated by two features: (1) A broad low that is almost completely encircled by local highs and (2) a large step across the San Jacinto fault. The isostatic gravity map (fig. 3) also shows these prevailing features but tends to emphasize an opening of the broad gravity low southwestward.

The broad gravity low is associated mostly with the thick body of Mesozoic quartz monzonite comprising much of the San Bernardino Mountains. The encircling local highs are associated with bands of gneiss or with local intrusions of more mafic rocks, such as diorite and gabbro, into the quartz monzonite. Many of these local gravity highs correlate with local magnetic highs, indicating that the small intrusive bodies are both denser and more magnetic than the large body of quartz monzonite.

The gravity gradient along the San Jacinto fault is much more vividly expressed than that in the vicinity of the San Andreas fault; this gravity step along the San Jacinto fault reaches an amplitude of as much as $40 \mathrm{mGal}$ near San Bernardino, the high side being on the southwest. This gravity step may manifest not only a steep attitude of the San Jacinto fault that separates crustal blocks of large density contrast but also a shallower attitude of the neighboring San Andreas fault to the north, which presumably separates rocks of smaller density contrast.

The magnetic anomaly map (fig. 4) in and surrounding the northern SBNF area is dominated by a northwest-trending string of narrow, large-amplitude highs along the San Andreas fault. This string of highs, which is expressed as sharply as a string of paternoster lakes on a topographic map, extends along the fault from a little west of long $116^{\circ} \mathrm{W}$. to a little west of long $118^{\circ} \mathrm{W}$., a distance of more than $185 \mathrm{~km}$ (115 mi) (note the 160-nT contour line of fig. 4). We denote many of these local paternoster highs by the labels M1-M9 (fig. 4). In the western part of the study area, M1 through M5 are associated with gneiss that occurs along the northeast side of the fault; southeast of M5, the fault bifurcates into a north and a south branch. M6 and M7 are associated with gneiss lodged between the north and south branches of the fault. M8 and M9 are associated with gneiss northeast of the north branch of the fault. These local magnetic highs have various gravity expressions. For example, M1 and M2 overlie a steep gravity gradient near the convergence of the San Andreas and San Jacinto faults; M3 and M4 occupy a gravity high that represents a broadening of this gradient; M5 and M6 occur in a region of lower gravity anomaly values; and M7, M8, and M9 overlap a pair of salient adjoining gravity highs. Where the magnetic highs are largest in amplitude, neglecting possible topographic influences, the gneiss is inferred to consist of gneissic hornblende-biotite quartz diorite and granodiorite, similar to the more mafic of two major gneissic granitoid units mapped by Morton and others (1980) in the San Gorgonio Wilderness area, within the southeastern part of the northern SBNF area.

To the north of the branches of the San Andreas fault, M10, which coincides with a local gravity high, is associated with Mesozoic granodiorite of Anderson Peak (Morton and others, 1980) that is more magnetic and dense than adjacent quartz monzonite. M11, which is the largest-amplitude high in the SBNF area and which coincides with a local gravity high, is caused by magnetic and 
dense Jurassic hornblende diorite and gabbro. Because these intrusive rocks lie in contact with Cambrian limestone, it is possible that subsurface skarn also contributes to these highs.

M12 and M13 are associated with Triassic monzonite, and M14, like M11, is associated with hornblende diorite and gabbro. Here, too, occurrences of limestone in contact with intrusive rocks imply that skarn may contribute to the anomalies, although none of these magnetic highs correlates with a definite gravity signature. Highs M15 through M18, at the northeastern margin of the northern SBNF area, are examples of small-amplitude highs that are generated by weakly to moderately magnetic, meta-igneous rocks. For example, ten miles east of M11, M15 coincides with a local gravity high and is associated with a largely hidden local body of magnetic and dense gneiss. M16 to the north, which is in a region of higher gravity values, is associated with a combination of magnetic and dense gneiss and granodiorite. M17 and M18, which show no distinctive gravity pattern, are associated with weakly magnetic quartz monzonite.

The pronounced northwest-trending magnetic low that lies north and northeast of highs M11-M14 is a manifestation of the negative polarization effects inherently connected with the lower extremities of magnetic bodies to the south. The east-west-trending low between M10 and M11 is also an example of such a polarization effect. Where these polarization lows occur, the underlying terrane may be considered to be largely nonmagnetic. There is no evidence that any of the magnetic lows in the SBNF area, regardless of amplitude, is associated with reversed or anomalously directed remanent magnetization of crustal rocks, although such a possibility cannot be dismissed.

Apart from M11, perhaps the most conspicuous magnetic feature within the northern SBNF area is the east-west-trending, narrow, large-amplitude high, labeled M19 and M20, at the western extremity of the study area, southwest of the San Andreas fault and southeast of Cucamonga Peak. This high was recognized in an earlier reconnaissance aeromagnetic survey of the San Andreas fault (Hanna and others, 1972) but its exact morphological expression remained unknown until a later, more detailed survey was flown (U.S. Geological Survey, 1981; Pankratz, 1982). The source of this high remains enigmatic. Much of the high spatially correlates with a thick zone of alteration that has been mapped as the "Black Belt" Mylonite unit by Bortugno and Spittler (1986). It is possible that quartz diorite in contact with this mylonite zone to the north is the principal source of the high; however, this quartz diorite appears to be relatively nonmagnetic a short distance to the west in this region. It is also possible that an east-west-trending belt of high-grade metamorphic rocks immediately south of the mylonite zone causes the high; however, the location of the maximum of the magnetic high seems too far north of these exposed metamorphic rocks to convincingly demonstrate a causal relationship. Because the magnetic high coincides with an east-west-trending gravity high, its source is undoubtedly both strongly magnetic and highly dense, possibly hidden gabbro or ultramafic rocks.

The boundary point maps showing maximum horizontal gradients of gravity and pseudogravity anomalies (figs. 3 and 4) reveal that few inferred steep boundaries of anomalous magnetization coincide with inferred steep boundaries of anomalous density in the SBNF area. This lack of coincidence does not imply that magnetic features do not correlate with gravity features, for as previously noted, they do often correlate with one another. Rather, the boundary point maps reveal that within and surrounding the SBNF area most broad regions that are anomalously magnetic do not coincide with most broad regions that are anomalously dense. A notable exception to this lack of coincidence, however, is an oval set of boundary points that delineates the source of magnetic high M11 and its superposed gravity high. We note that some of the general lack of coincidence of boundary points is also attributable to the abundance of highly diverse rock compositions and to structural deformation that has profoundly altered the morphological expressions of some rock bodies. 


\section{Mineral Resources}

Few, if any, metallic mineral occurrences of economic value have been found in the Precambrian gneiss-plutonic complex in and surrounding the study area, which serve as sources of some magnetic and gravity highs. However about $320 \mathrm{~km}(200 \mathrm{mi})$ northeast of the study area, such a crystalline complex hosts oxide ores of rare earth minerals found in carbonatite in the Clark Mountain area near Mountain Pass, California.

The occurrence of large dolomite, limestone, and marble bodies in contact with plutonic rocks in the San Bernardino Mountains admits the possibility that skarn has developed at thermally metamorphosed contacts. Such skarns, if present, can contain minerals of interest, such as tungsten and magnetite, and are commonly very magnetic. For example about $95 \mathrm{~km}(60 \mathrm{mi})$ east of Indio, in Riverside County, economically significant, tabular bodies of magnetite occur within a contact-metamorphosed dolomite in close proximity to a quartz monzonite intrusion (Scott and Wilson, 1980). Although other occurrences of massive replacement magnetite deposits are known in the Mojave Desert terrane north and east of the study area, none has been recognized within or near the study area.

Future magnetic surveys based on flight lines spaced much closer (say, no more than $1 \mathrm{~km}$ apart) than those of the present data set might reveal that some magnetic highs are associated with mineralized zones and that some magnetic lows are associated with hydrothermally altered rocks, such as occurs in the Bighorn Mountains Wilderness Study Area (Matti and others, 1982) at the northeastern margin of the northern SBNF area. The available, relatively sparse data indicate that the SBNF area, like the Morongo Wilderness Study Area (Matti and others, 1987) a few miles east of the northern SBNF area, are devoid of large (long wavelength) anomaly features that might correspond to large tracts of mineral occurrences. More detailed data, however, are needed to evaluate the potential for occurrence of small (short wavelength) anomaly features that might correlate with local mineral deposits. 


\section{LANDSAT THEMATIC MAPPER (TM) STUDY OF NORTHERN PART}

\section{TM Characteristics and Data Processing}

Two quadrants of a TM scene (ID-500221749) that was recorded on March 23, 1984 were processed for this study. This late winter scene, which has a relatively low-sun angle, corresponds to the northern part of the SBNF within San Bernardino County. Landsat TM imagery has 28.5-m resolution, six spectral bands in the visible and near-infrared (table 1), and excellent radiometric and geometric characteristics.

Table 1.-Landsat spectral bands

\begin{tabular}{cc}
\hline Band & $\begin{array}{c}\text { Wavelength coverage } \\
\text { (micrometers) }\end{array}$ \\
\hline 1 & $0.45-0.52$ \\
2 & $0.52-0.60$ \\
3 & $0.63-0.69$ \\
4 & $0.76-0.90$ \\
5 & $1.55-1.75$ \\
7 & Thermal IR, not used in this study \\
& $2.08-2.35$ \\
\hline
\end{tabular}

Red, green, and blue color composite images use three spectral bands to enhance color differences of surface materials and maximize the display of lithologic spectral radiance data recorded by the Landsat Thematic Mapper. Ratioing of selected bands minimizes the influence of topography thereby increasing the influence of spectral information in the ratio image. Color compositing of three, stretched ratio images to form a color-ratio composite (CRC) image provides additional separation of spectrally similar materials by increasing their perceptual discrimination. The lack of topographic expression in the images makes it difficult to interpret the compositional variations in a geomorphic and geologic context. A method for adding back topographic information to the ratios is discussed later. Rocks and soils that are mineralogically and spectrally similar may not be separated.

Digital image processing was done using REMAPP (Sawatzky, 1985; see also Livo, 1990), a software package that was developed over more than 15 years for processing digital satellite data. The processing methods we used were adapted by D. H. Knepper, Jr. (written commun., 1992) from a procedure described by Crippen (1990a, 1990b).

Before ratios were formed, each band was atmospherically corrected to remove the effects of atmospheric scattering (Crippen, 1990a) that distorts the signal recorded from the ground surface by the TM sensor. TM ratios 5/7,5/4, and $3 / 1$ were written to film as red, green, and blue, respectively, to form a CRC for interpretation. The result of this process is an image that depicts variations in iron as blue or green, hydroxyl-bearing minerals and carbonates as variations in red and vegetation as red (table 2). 
Table 2.-Resultant colors of minerals and vegetation on a CRC image prepared with TM 5/7 in red, TM 5/4 in green, and TM $3 / 1$ in blue

\begin{tabular}{|c|c|c|c|c|}
\hline Material & $\begin{array}{l}\text { TM 5/7 } \\
\text { (red) }\end{array}$ & $\begin{array}{l}\text { TM 5/4 } \\
\text { (green) }\end{array}$ & $\begin{array}{l}\text { TM 3/1 } \\
\text { (blue) }\end{array}$ & $\begin{array}{l}\text { Resultant } \\
\text { color }\end{array}$ \\
\hline $\begin{array}{l}\mathrm{CO}_{3}, \mathrm{OH} \text {-bearing } \\
\text { minerals, and } \\
\text { vegetation }\end{array}$ & HIGH & LOW & LOW & RED \\
\hline $\mathrm{Fe}^{+2}$ & LOW & HIGH & LOW & GREEN \\
\hline $\mathrm{Fe}^{+2}$ & LOW & LOW & HIGH & BLUE \\
\hline $\begin{array}{l}\mathrm{CO}_{3}, \mathrm{OH} \text {-bearing } \\
\text { minerals, vegetation, } \\
\text { and } \mathrm{Fe}^{+2}\end{array}$ & HIGH & MODERATE & HIGH & $\begin{array}{l}\text { YELLOW } \\
\text { to WHITE }\end{array}$ \\
\hline $\begin{array}{l}\mathrm{CO}_{3}, \mathrm{OH} \text {-bearing } \\
\text { minerals, vegetation, } \\
\text { and } \mathrm{Fe}^{+3}\end{array}$ & HIGH & LOW & HIGH & MAGENTA \\
\hline
\end{tabular}


Color prints made from a film transparency were enlarged for interpretation. Color paper copies were made on a Calcomp plotter at various scales for overlaying on geological and geophysical maps. Nuances of color and tonal differences are lost in the Calcomp copies so that reference to the color prints and the original color transparency was necessary to better interpret the CRC image.

\section{Interpretation of Thematic Mapper Data}

The resultant color-ratio composite image (fig. 5) may be used to detect the presence of broad groups of minerals, ferrous and ferric iron, and vegetation. However, because of the width of TM band 7 $(2.08$ to $2.35 \mu \mathrm{m})$ those minerals which display absorption bands within this wavelength region cannot be separated. Hydroxyl-bearing minerals such as muscovite and clays that display absorption features near $2.2 \mu \mathrm{m}$ will not be separated from carbonate minerals that have absorption features near $2.31 \mu \mathrm{m}$ (dolomite) and $2.33 \mu \mathrm{m}$ (calcite) (fig. 6).

As a result, the discrimination of carbonate rocks from granite, gneiss, micaceous quartz monzonite, and quartzite is very difficult using TM data. In addition, lithological discrimination is even more difficult in areas of moderate vegetation cover such as the San Bernardino mountains. Vegetation has a high 5/7 spectral signature as it also displays absorption features in the TM 7 wavelength region.

The red color that predominates in the SBNF CRC scene is due to the vegetation cover. For example, rectangular fields with crops in the SW corner of the scene are clearly delineated. The deepest red pixels correspond to highest elevations where vegetation is more dense.

Also distinctive are clusters of white pixels which may be traced along stream channels and active washes where unconsolidated alluvium consisting of sand and pebble to boulder gravel is exposed. Similar Holocene fill in two small glacier-formed lake basins, near San Gorgonio Mountain (Morton and others, 1980) also are white. Landslides and fan deposits, for example along the north branch of the San Andreas fault, are also white because of the exposed alluvial material. Along the northern margins of the SBNF, quarries as well as alluvium and landslide rubble correspond to clusters of white pixels.

However, as carbonate rocks in the area are considered to be economically important, we proceeded with visual examination of the CRC scene to determine if there were any tonal, chromatic, or textural characteristics displayed in the CRC scene by the known carbonate outcrops which could be used to enlarge the mapped carbonate lithological boundaries.

Just to the northeast of Big Bear Lake (figs. 1 and 5) a large exposure of the Furnace Limestone is mapped (Dibblee, 1964). The limestone is also mapped along the northern and northeastern borders of the SBNF where there are several quarries. The large northern exposure particularly has a brown hue but this brown color is common to all of the mapped outcrops of limestone. A relatively greater contribution of green (ferrous iron) than blue (ferric iron) to the pixels which correspond to the mapped limestone would result in the brown color. To the north of Baldwin Lake (fig. 1) a large body of quartzite is mapped. Although the quartzite could be expected to be displayed as a similar color, it does not have the brownish color of the limestone (fig. 5).

The quartzite which crops out at Gold Mountain, north of Big Bear City appears red to magenta on the image (figs. 1 and 5), although it crops out at an elevation $(2,508 \mathrm{~m})$ similar to the limestone $(2,499 \mathrm{~m})$ just to the west. This indicates that color differences between the quartzite and limestone as displayed on the image are not necessarily due to those vegetation differences which are related to elevation. However, in arid regions, vegetation density and species distribution on outcrops may vary according to lithological characteristics (porosity, permeability, trace elements). This may explain color variations which are not primarily caused by mineralogical differences. 
The dominant intrusive rock type in the area covered by this scene is quartz monzonite, which commonly is spectrally more flat than carbonate-, micaceous-, or clay-bearing rocks. Pixels on the image that correspond to this rock type are red (denser vegetation cover) to purple (vegetation plus ferric iron). Another explanation for the hue differences from brown to purple is the variation of limonite or other ferric iron oxides on weathered surfaces of the different rock types and derived soils. The iron content of carbonate rocks and soils may be reduced in contrast to that of the other surface materials exposed in the scene. Spectral reflectance laboratory measurements of samples of the major lithologies might verify this explanation.

Based on these criteria, previously unmapped carbonate rocks on the image may be indicated by clusters of pixels that have the same spectral response (brown hue) as those that correspond to the known limestone and marble outcrops. The shape and size of the mapped carbonate outcrops may be found to more closely follow the outline of corresponding brown pixels on the image. Field checking of some selected areas would be necessary for validation. 


\section{GRAVITY AND MAGNETICS OF SOUTHERN PART}

The southern part of the SBNF is located in the northeastern part of the Peninsular Ranges province of California (Jahns, 1954) and lies predominantly within the San Jacinto Mountains, but includes parts of the Santa Rosa Mountains and San Jacinto and Coachella Valleys. The southern part of the SBNF occupies a zone that is bounded by several major faults that include the San Jacinto, Banning, and San Andreas faults. In addition, a north-trending zone of mylonitic shearing adjacent to Palm Canyon occupies the eastern part of the study area. The San Jacinto Mountains are chiefly composed of Mesozoic felsic plutonic rocks and a north-trending belt of Paleozoic metasedimentary rocks (Rogers, 1965). Previous geophysical work in the vicinity of southern part of the SBNF include studies of the Salton trough (Biehler, 1964), seismic and gravity studies in San Jacinto Valley (Fett, 1968; Cordell, 1973), and a mineral resource study of the San Jacinto Wilderness located in the San Jacinto Mountains (Cox and others, 1983).

Gravity

In the southern part of the SBNF Bouguer gravity anomaly values range from about -118 to -76 $\mathrm{mGal}$ (fig. 2), whereas isostatic gravity anomaly values range from about -46 to $6 \mathrm{mGal}$ (fig. 3). San Jacinto and Coachella Valleys are characterized by high-amplitude gravity lows with steep gradients while the intervening San Jacinto and Santa Rosa Mountains are characterized by a gravity high. San Jacinto Valley is a narrow, northwest-trending valley along the San Jacinto Fault Zone. Its associated gravity low is about $35 \mathrm{~km}$ long, about $6 \mathrm{~km}$ wide, and has an amplitude of about $25 \mathrm{mGal}$. Similarly, Coachella Valley is a narrow northwest-trending valley along the San Andreas Fault Zone, about 70 by $15 \mathrm{~km}$, and has a gravity anomaly amplitude of about $25 \mathrm{mGal}$. Fett (1968) determined a minimum depth to basement of $2.4 \mathrm{~km}$ in the center of the San Jacinto graben based on seismic refraction data and used a 5-layer density model to reproduce the measured gravity anomaly (see Cordell, 1973). Cordell (1973) using Fett's gravity data showed that the depth to basement computed using an exponential density-depth function was consistent with the 2.4-km minimum depth to basement inferred from seismic data. A gravity study of the Salton trough by Biehler (1964) indicated that the depth to basement in Coachella Valley was at least 4.7 $\mathrm{km}$ and that basin filling sedimentary rocks are thickest on the northeast side of the valley (see Griscom, 1980). A depth-to-basement model of southern California using a multi-layer densitydepth function suggests that both these pull-apart basins are probably about 4-5 $\mathrm{km}$ deep (R.C. Jachens, oral commun., 1991).

The San Jacinto Mountains are the highest mountains in the eastern part of the Peninsular Ranges province reaching an elevation of $3,293 \mathrm{~m}(10,804 \mathrm{ft})$ at San Jacinto Peak and 2,690 $\mathrm{m}(8,824 \mathrm{ft})$ at Tahquitz Peak (fig. 1). According to Oliver (1980) regional gravity variations in the eastern part of the province correlate to average elevation variations suggesting that this part of the province is in approximate isostatic balance. The San Jacinto Mountains are bounded by steep gravity gradients on the southwest and northeast that probably represent near vertical range front faults.

Recently collected gravity data within the San Jacinto Mountains combined with physical property measurements (Mariano and others, unpub. data, 1989; D.A. Ponce and others, unpub. data, 1991) show that plutonic rocks of the San Jacinto Mountains are generally less dense than adjacent metasedimentary rocks. About 15 samples of felsic granitic rocks have a range in density of 2.60 to 2.71 with an average of $2.65 \mathrm{~g} / \mathrm{cm}^{3}$, while 6 samples of metasedimentary rocks have a range in density of 2.69 to 2.86 with an average of $2.73 \mathrm{~g} / \mathrm{cm}^{3}$.

A gravity high of about $6 \mathrm{mGal}$ is associated with exposed metasedimentary rocks southeast of Tahquitz Peak. Northward and along the strike of these metasedimentary rocks is another gravity high of about $5 \mathrm{mGal}$ that occurs over exposed plutonic rocks northeast of San Jacinto Peak. Although this anomaly may in part be related to terrain correction errors in the more rugged parts of 
the San Jacinto Mountains, it is probably related to denser, more mafic plutonic rocks at depth. The causative feature of this anomaly is probably buried metasedimentary rocks similar to those exposed near Tahquitz Peak. However, because of sparse gravity data control, it's difficult to determine whether or not they are contiguous. The east edge of the anomaly is defined by a linear trend in the maximum horizontal gradients of isostatic gravity anomalies that correspond with a north-trending zone of mylonitic shearing adjacent to the Palm Canyon Fault (Rogers, 1965).

\section{Magnetics}

The aeromagnetic field of the southern part of the SBNF is conspicuously different from that of the northern part and is characterized by a lack of magnetic anomalies, especially over the San Jacinto Mountains (fig. 4). This terrane, defined by the lack of magnetic anomalies, is bounded by the San Jacinto fault zone to the west and the San Andreas Fault zone to the north and east. Southward, this geophysical terrane broadens, especially to the west where it is approximately delimited by the Elsinore fault zone, and extends beyond the California-Mexico border. The western edge of this terrane probably marks a transition between oceanic crust intruded by more mafic plutons on the west to continental crust intruded by more felsic plutons to the east (Jachens and others, 1986; Todd and others, 1988).

The largest anomalies in the southern part of the SBNF are on the order of only $40 \mathrm{nT}$ associated with metasedimentary rocks that extend southeast from Tahquitz Peak to the Santa Rosa Mountains (Rogers, 1965). Magnetic and physical property data (D.A. Ponce and others, unpub. data, 1991) indicate that plutonic rocks of the San Jacinto Mountains are essentially nonmagnetic and that metasedimentary rocks are only slightly magnetic. The lack of magnetic anomalies is consistent with the lack of gravity anomalies associated with plutonic rocks of the San Jacinto Mountains indicating that there are no major mass or magnetization anomalies within the southern part of the SBNF.

\section{Mineral Resources}

A mineral resource study by Cox and others (1983) indicates that no anomalous mass or magnetization concentrations that might be associated with mineralization are present in the San Jacinto Wilderness. However, if gravity data are only partly affected by errors in terrain corrections in the highest parts of the San Jacinto Mountains, near San Jacinto Peak, an anomalous mass concentration is present. Based on the shape and amplitude of the gravity anomaly this anomalous mass is presumed to be metasedimentary rocks similar to and on strike with those exposed near Tahquitz Peak. Although no evidence of significant mineralization was observed (see Cox and others, 1983), these metasedimentary rocks and their intrusive contacts with plutonic rocks may be potential areas of mineralization. 


\section{REFERENCES}

Allen, C.R., and Meisling, K.E., 1983, Neotectonics of the north frontal fault system of the San Bernardino Mountains, southern California: U.S. Geological Survey Report, Office of Earthquake Studies External Research Program, Semi-annual Technical Report, Dec. 1, 1980-May 31, 1981, Contract 14-08-0001-19754, 10 p. [A copy of this report is available from the library of the U.S. Geological Survey, Reston, Va., under catalog no. (200) Al53n.]

Andreasen, G.E., Pitkin, J.A., and Petrafeso, F.A., 1964a, Aeromagnetic map of eastern Los Angeles, California, and vicinity: U.S. Geological Survey Geophysical Investigations Map GP465 , scale $1: 48,000$.

1964b, Aeromagnetic map of the Long Beach-Santa Ana area, Los Angeles and Orange counties, California: U.S. Geological Survey Geophysical Investigations Map GP-464, scale $1: 48,000$.

Bailey, E.H., ed., 1966, Geology of northern California: California Division of Mines and Geology Bulletin 190, 508 p. [fig. 1: physiographic provinces: Transverse Ranges-Peninsular Ranges]

Baird, A.K., Baird, K.W., and Welday, E.E., 1979, Batholithic rocks of the northern Peninsular and Transverse Ranges, southern California: chemical composition and variation, in Abbott, P.L., and Todd, V.R., eds., Mesozoic crystalline rocks: Peninsular Ranges batholith and pegmatites, Point Sal ophiolite: San Diego, California, San Diego State University, Department of Geological Sciences, p. 111-132.

Baranov, Wladimir, 1975, Potential fields and their transformations in applied geophysics: BerlinStuttgart, Gebruder Borntraeger, $121 \mathrm{p}$.

Biehler, Shawn, 1964, Geophysical study of the Salton trough of southern California: Ph.D. dissertation, California Institute of Technology, $139 \mathrm{p}$.

Biehler, Shawn, Langenheim, V.E., Sikora, R.F., Chapman, R.H., and Beyer, L.A., 1992, Complete Bouguer gravity anomaly map of the Santa Ana $1^{\circ}$ by $2^{\circ}$ quadrangle: U.S. Geological Survey Open-File Report, scale 1:250,000.

Biehler, Shawn, Tang, R.W., Ponce, D.A., and Oliver, H.W., 1988, Bouguer gravity map of the San Bernardino quadrangle, California: California Division of Mines and Geology Map no. 3B, scale 1:250,000.

Blake, Jr., M.C., Zietz, Isidore, and Daniels, D.L., 1978, Aeromagnetic and generalized geologic map of parts of central California: U.S. Geological Survey Geophysical Investigations Map GP-918, scale 1:1,000,000.

Blakely, R.J., and Simpson, R.W., 1986, Approximating edges of source bodies from gravity or magnetic data: Geophysics, v. 51, p. 1494-1498.

Bond, K.R., and Zietz, Isidore, 1987, Composite magnetic-anomaly of the conterminous United States west of $96^{\circ}$ longitude: U.S. Geological Survey Geophysical Investigations Map GP977, scale 1:2,500,00. 
Bortugno, E.J., and Spittler, T.E., 1986, Geologic map of California, San Bernardino sheet: California Division of Mines and Geology Map, scale 1:250,000.

Brown, H.J., 1991, Stratigraphy and paleogeographic setting of Paleozoic rocks in the San Bernardino Mountains, California, in Cooper, J.D., and Stevens, C.H., eds., Paleozoic paleogeography of the western United States-II: Pacific Section SEPM, v. 67, p. 193-207.

Cordell, Lindreth, 1973, Gravity analysis using an exponential density-depth function-San Jacinto graben, California: Geophysics, v. 38, no. 4, p. 684-690.

Cordell, Lindreth, and Grauch, V.J.S., 1983, Mapping basement magnetization zones from aeromagnetic data in the San Jaun Basin, New Mexico, in Hinze, W.J., ed., The utility of regional gravity and magnetic anomaly maps: Society of Exploration Geophysicists, Tulsa, Oklahoma, p. 201-214.

Cox, B.F., Matti, J.C., Oliver, H.W., and Conyac, M.D., 1983, Mineral resource potential of the San Jacinto Wilderness, Riverside County, California: U.S. Geological Miscellaneous Field Studies Map MF-1159-B, 5 p., scale 1:62,500.

Crippen, R.E., 1990a, The iterative ratioing method of determining atmospheric corrections for scenes with rugged terrain: Submitted to Photogrammetric Engineering and Remote Sensing.

1990b, Image display of four components of spectral data: Submitted to Remote Sensing of Environment.

Cummings, David, and Regan, R.D., 1976, Aeromagnetic survey of the San Gabriel anorthosite complex, San Gabriel Mountains, southern California: Geological Society of America Bulletin, v. 87, p. 675-680.

Dibblee, T.W., 1964, Geologic map of the Lucerne Valley Quadrangle, San Bernardino County, California: U.S. Geological Survey Miscellaneous Investigations Map I-426, scale 1:62500.

Dobrin, M.B., and Savit, C.H., 1988, Introduction to Geophysical Prospecting (4th ed.): New York, McGraw-Hill, 867 p.

Ellsworth, W.L., 1990, Earthquake history, 1769-1989, in Wallace, R.E., ed., The San Andreas fault system, California: U.S. Geological Survey Professional Paper 1515, p. 152-187.

Fett, J.D., 1968, Geophysical investigation of the San Jacinto Valley, Riverside County, California: University of California, Riverside, unpublished thesis, $87 \mathrm{p}$.

Grauch, V.J.S., and Cordell, L.E., 1987, Limitations of determining density or magnetic boundaries from the horizontal gradient of gravity or pseudogravity data: Geophysics, v. 52, p. 118-121.

Griscom, Andrew, 1980, Salton trough, in Oliver, H.W., ed., 1980, Interpretation of the gravity map of California and its continental margin: California Division of Mines and Geology Bulletin 205 , p. $20-21$.

Griscom, Andrew, and Jachens, R.C., 1990, Crustal and lithospheric structure from gravity and magnetic studies, in Wallace, R.E., ed., The San Andreas fault system, California: U.S. Geological Survey Professional Paper 1515, Chapter 9, p. 238-259.

Hadley, David, and Kanamori, Hiroo, 1977, Seismic structure of the Transverse Ranges, California: Geological Society of America Bulletin, v. 88, no. 10, p. 1469-1478. 
Hanna, W.F., Brown, R.D., Jr., Ross, D.C., and Griscom, Andrew, 1972, Aeromagnetic reconnaissance and generalized geologic map of the San Andreas fault between San Francisco and San Bernardino, California: U.S. Geological Survey Geophysical Investigations Map GP-815, 8 p., scale 1:250,000.

Hauksson, Egill, Jones, L.M., Davis, T.L., Hutton, Katherine, Brady, A.G., Reasenberg, P.A., Michael, A.J., Yerkes, R.F., Williams, Patrick, Reagor, Glen, Stover, C.W., Bent, A.L., Shakai, A.K., Etheridge, Edwin, Porcella, R.L., Bufe, C.G., Johnston, M.J.S., and Cranswick, Edward, 1988, The 1987 Whittier Narrows earthquake in the Los Angeles metropolitan area, California: Science, v. 239, p. 1409-1412.

High Life Helicopters, Inc., and Q.E.B., Inc., 1980, Airborne gamma-ray and magnetometer survey, Los Angeles, San Bernardino, Santa Ana, and San Diego quadrangles, California: U.S. Department of Energy, National Uranium Resource Evaluation (NURE) Report GJBX$214(80), 5$ v., 640 p.; residual intensity magnetic anomaly contour map GJM-457(83), scale $1: 500,000$.

Hildenbrand, T.G., 1983, FFTFIL-A filtering program based on two-dimensional Fourier analysis: U.S. Geological Survey Open-File Report 83-237, 30 p.

Hill, P.L., 1991, Bibliographies and location maps of publications on aeromagnetic and aeroradiometric surveys for the states west of approximately $104^{\circ}$ longitude (exclusive of Hawaii and Alaska): U.S. Geological Survey Open-File Report 91-370-A, 172 p.

International Union of Geodesy and Geophysics, 1971, Geodetic Reference System 1967: International Association of Geodesy Special Publication no. 3, $166 \mathrm{p}$.

Jachens, R.C., and Griscom, Andrew, 1985, An isostatic residual gravity map of California-A residual map for interpretation of anomalies from intracrustal sources, in Hinze, W.J., ed., The utility of regional gravity and magnetic anomaly maps: Society of Exploration Geophysicists, Tulsa, Oklahoma, p. 347-360.

Jachens, R.C., and Roberts, C.W., 1981, Documentation of a FORTRAN program, 'isocomp', for computing isostatic residual gravity: U.S. Geological Open-File Report 81-574, 26 p.

Jachens, R.C., Simpson, R.W., Griscom, Andrew, and Mariano, J., 1986, Plutonic belts in southern California defined by gravity and magnetic anomalies (abs.): Geological Society of America Abstracts with Programs, v. 18, p. 120.

Jahns, R.H., 1954, Investigations and problems of southern California geology, in Jahns, R.H., ed., Geology of southern California: California Division of Mines and Geology Bulletin 170, p. 529.

Jennings, C.W., 1977, Geologic map of California: California Division of Mines and Geology, Geologic Data Map No. 2, scale 1:750,000.

Langenheim, V.E., Chapman, R.H., Sikora, R.F., Ponce, D.A., and Dixon, E.T., 1991, Isostatic residual gravity map of the Santa Ana 1:100,000-scale quadrangle, California: U.S. Geological Survey Open-File Report 91-555.

Livo, K.E., 1990, REMAPP-PC remote sensing image processing software for MS-DOS personal computers: U.S. Geological Survey Open-File Report 90-88, 58p. 
Lourenco, J.S., 1972, Analysis of three-component magnetic data: Berkeley, Calif., University of California Ph. D. thesis, $153 \mathrm{p}$.

Luyendyk, B.P., Kamerling, M.J., and Terres, Richard, 1980, Geometric model for Neogene crustal rotations in southern California: Geological Society of America Bulletin, v. 91, p.211-217.

Mabey, D.R., 1960, Gravity survey of the western Mojave Desert, California: U.S. Geological Survey Professional Paper 316-D, p. 51-73.

Matti, J.C., Carson, S.E., Kilburn, J.E., Griscom, Andrew, Prose, D.V., and Kuizon, Lucia, 1987, Mineral resources of the Morongo Wilderness Study Area, San Bernardino County, California: U.S. Geological Survey Bulletin 1710, 8 p.

Matti, J.C., Cox, B.F., Rodriguez, E.A., Obi, C.M., Powell, R.E., Hinkle, M.E., Griscom, Andrew, Sabine, Charles, and Cwick, G.J., 1982, Mineral resource potential of the Bighorn Mountains Wilderness Study Area (CDCA-217), San Bernardino County, California: U.S. Geological Survey Miscellaneous Field Studies Map MF-1493-A, scale 1:24,000.

Morelli, C. (Ed.), 1974, The International Gravity Standardization Net, 1971: International Association of Geodesy Special Publication no. 4, $194 \mathrm{p}$.

Morton, D.M., Cox, B.F., and Matti, J.C., 1980, Geologic map of the San Gorgonio Wilderness, San Bernardino County, California: U.S. Geological Survey Miscellaneous Field Studies Map MF1161-A, scale 1:62,500.

Namson, Jay, and Davis, Thom, 1988, Structural transect of the western Transverse Ranges, California-Implications for lithospheric kinematics and seismic risk evaluation: Geology, v. 16, p. $675-679$.

1989a, Reply to comments by R.J. Weldon and E.D. Humphreys on "Structural transect of the western Transverse Ranges, California: Implications for lithospheric kinematics and seismic risk evaluation": Geology, v. 17, p. 770- 771.

1989b, Reply to comments by R.S. Yeats and G.J. Huftile on "Structural transect of the western Transverse Ranges, California: Implications for lithospheric kinematics and seismic risk evaluation": Geology, v. 17, p. 772-773.

Oliver, H.W., ed., 1980, Interpretation of the gravity map of California and its continental margin: California Division of Mines and Geology Bulletin 205, $52 \mathrm{p}$.

Oliver, H.W., Chapman, R.H., Biehler, Shawn, Robbins, S.L., Hanna. W.F., Griscom, Andrew, Beyer, L.A., and Silver, E.A., 1980, Gravity map of California and its continental margin: California Division of Mines and Geology, Geologic Data Map No. 3, 2 sheets, scale $1: 750,000$

Pankratz, Leroy, 1982, Aeromagnetic studies of the Sheep Mountain Wilderness Study Area and the Cucamonga Wilderness and additions, Los Angeles and San Bernardino Counties, California: U.S. Geological Survey Bulletin 1506-B, p. 29-32.

Peddie, N.W., 1983, International geomagnetic reference field-its evolution and the difference between new and old models for 1965-1980: Geophysics, v. 48, no. 12, p. 1691-1696. 
Plouff, Donald, 1977, Preliminary documentation for a FORTRAN program to compute gravity terrain corrections based on topography digitized on a geographic grid: U.S. Geological Survey Open-File Report 77-535, 45 p.

Ponce, D.A., and Langenheim, V.E., 1992, Isostatic residual gravity map of the Palm Springs 1:100,000-scale quadrangle: U.S. Geological Survey Open-File Report 92-702, 3 p., scale $1: 100,000$.

Roberts, C.W., Jachens, R.C., and Oliver, H.W., 1990, Isostatic residual gravity map of California and offshore southern California: California Division of Mines and Geology, Geologic Data Map No. 7, 2 sheets, scale 1:750,000.

Rogers, T.H., compiler, 1965, Geologic map of California, Santa Ana sheet: California Division of Mines and Geology Map, scale 1:250,000.

Sawatzky, D.L., 1985, Programmer's guide to REMAPP, REMote sensing Array Processing Procedures: U.S. Geological Survey Open-File Report 85-231, 21p.

Scott, H.S., and Wilson, R.L., 1980, Kaiser Steel Corporation mineral properties in the California Desert Conservation Area, in Fife, D.F., and Brown, H.R., Geology and mineral wealth of the California desert (Dibblee Volume): Santa Ana, Calif., South Coast Geological Society, p. 140-149.

Snyder, D.B., Roberts, C.W., Saltus, R.W., and Sikora, R.F., 1981, Magnetic tape containing the principal facts of 64,402 gravity stations in the State of California: U.S. Geological Survey Report, 30 p.; available from National Technical Information Service, U.S. Department of Commerce, Springfield, Virginia 22161, PB82-168287.

Tang, R.W., and Ponce, D.A., 1982, Principal facts, accuracies, sources, and base station descriptions for 4,915 gravity stations on the San Bernardino $1^{\circ}$ by $2^{\circ}$ quadrangle, California, U.S. Geological Survey Report, 99 p., available from National Technical Information Service, U.S. Department of Commerce, Springfield, Virginia 22161, PB82200312 .

Tennyson, M.E., 1989, Pre-transform early Miocene extension in western California: Geology, v. 17, p. $792-796$.

Todd, V.R., Erskine, B.G., and Morton, D.M., 1988, Metamorphic and tectonic evolution of the northern Peninsular Ranges batholith, southern California, in Ernst, W.G., ed., Metamorphism and crustal evolution of the western United States: Rubey Volume Vii, New Jersey, Prentice Hall, p. 649-682.

U.S. Geological Survey, 1979, Aeromagnetic map of the southern San Bernardino Mountains area, California: U.S. Geological Survey Open-File Report 79-1448, scale 1:62,500.

1981, Aeromagnetic map of the Cucamonga Peak area, California: U.S. Geological Survey Open-File Report 81-86, scale 1:62,500.

1982, Aeromagnetic map of the Bighorn area, California: U.S. Geological Survey Open-File Report 82-664, scale 1:62,500.

1987, Aeromagnetic map of the Ord Mountains area, southern California: U.S. Geological Survey Open-File Report 87-5, 9 sheets, scale 1:62,500. 
1990, Aeromagnetic map of parts of the San Diego, Santa Ana, and adjacent $1^{\circ} \times 2^{\circ}$ quadrangles, California: U.S. Geological Survey Open-File Report 90-206, scale 1:250,000.

Wallace, R.E., ed., The San Andreas fault system: U.S. Geological Survey Professional Paper 1515, $283 \mathrm{p}$.

Weldon II, R.J., and Humphreys, E.D., 1989, Comments on "Structural transect of the western Transverse Ranges, California: Implications for lithospheric kinematics and seismic risk evaluation": Geology, v. 17, p. 769-770.

Yeats, R.S., and Huftile, G.J., 1989, Comments on "Structural transect of the western Transverse Ranges, California: Implications for lithospheric kinematics and seismic risk evaluation": Geology, v. 17, p. 771-772.

Youngs, L.G., 1985, Aeromagnetic map of the San Bernardino $1^{\circ} \times 2^{\circ}$ sheet, California: California Division of Mines and Geology Open-File Report 85-20, scale 1:250,000.

1988, Aeromagnetic map of the Santa Ana $1^{\circ} \times 2^{\circ}$ quadrangle, California: California Division of Mines and Geology Open-File Report 88-8, scale 1:250,000. 


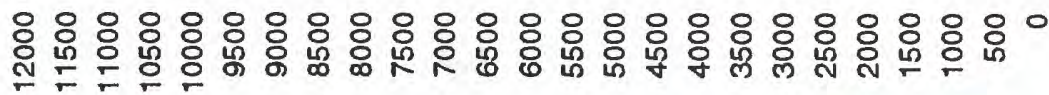
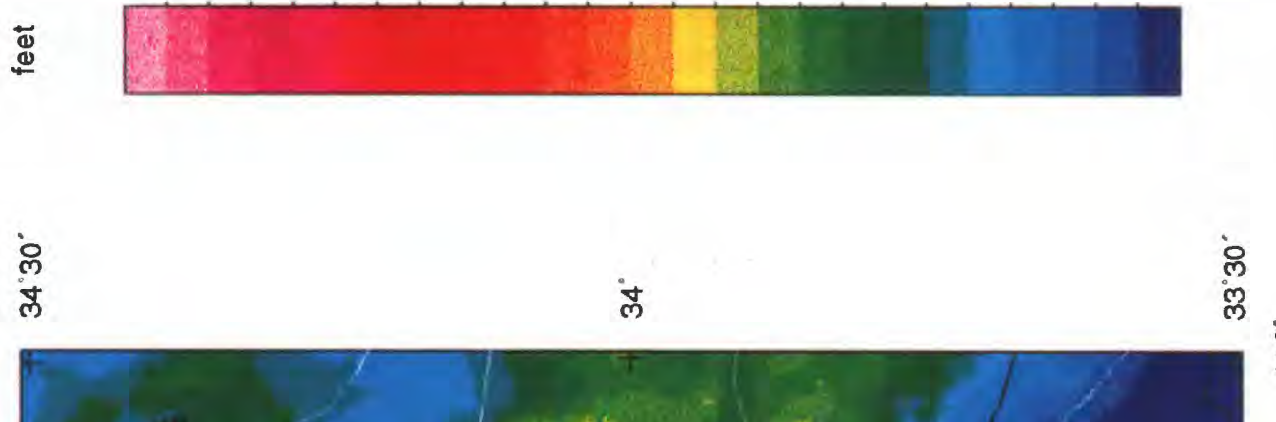

$\stackrel{0}{\square}$

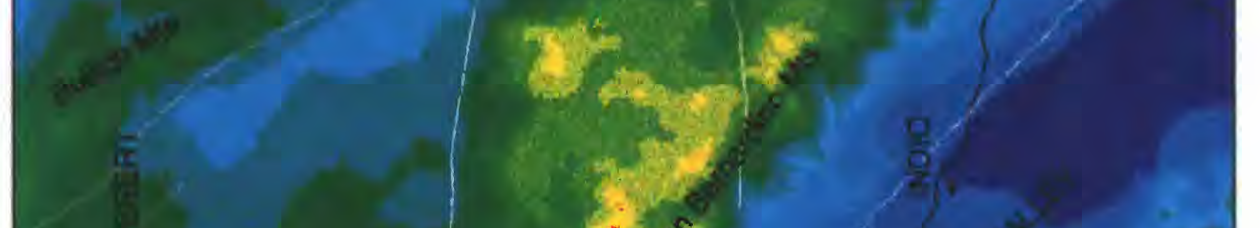

㧀.

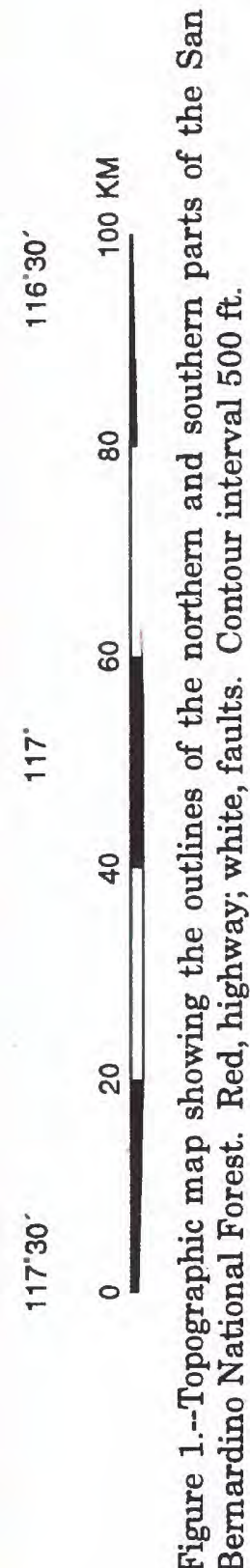




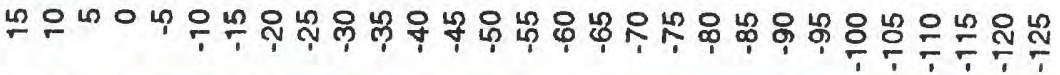
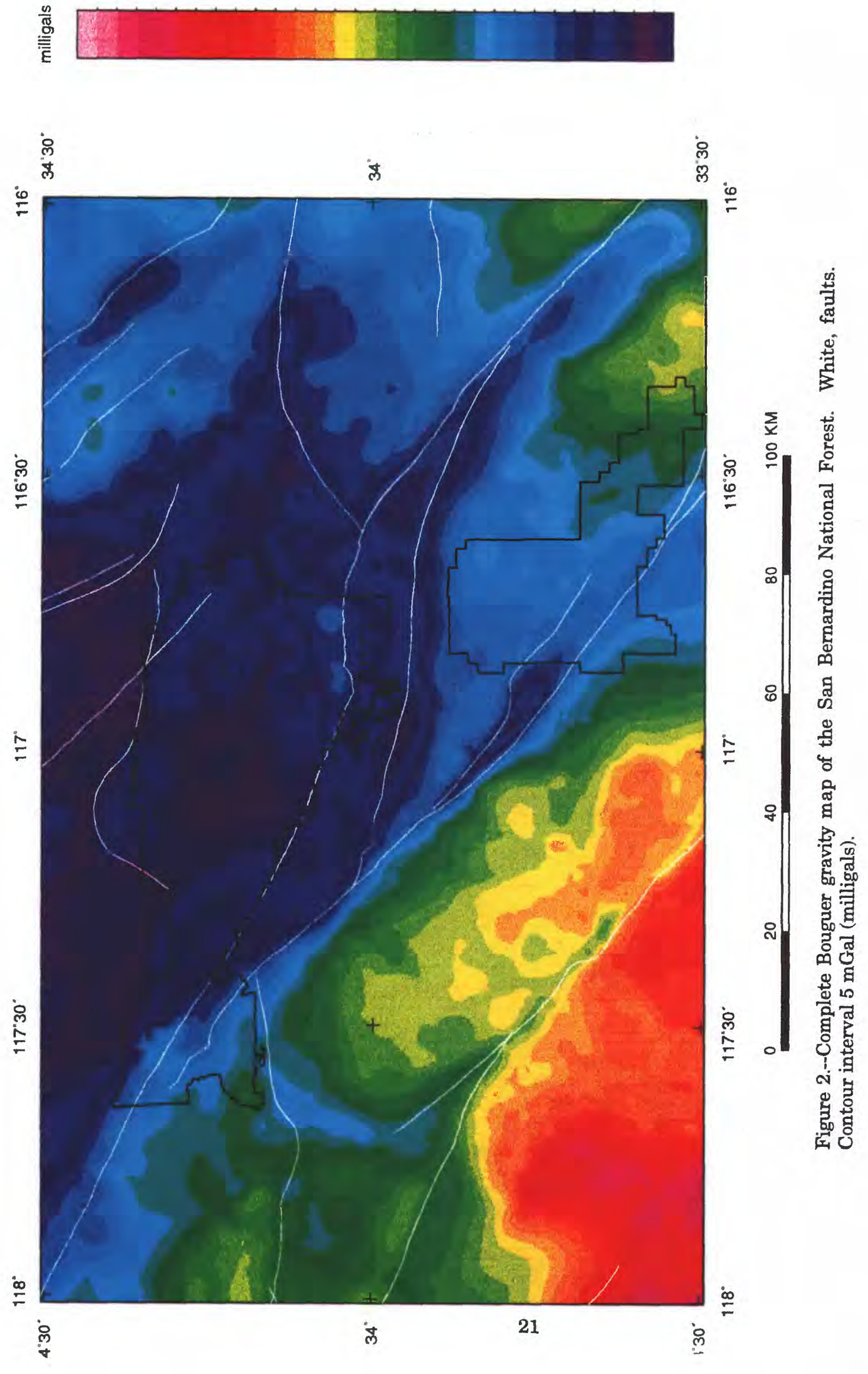


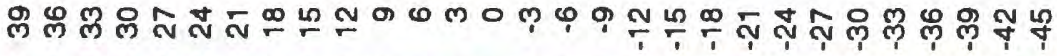

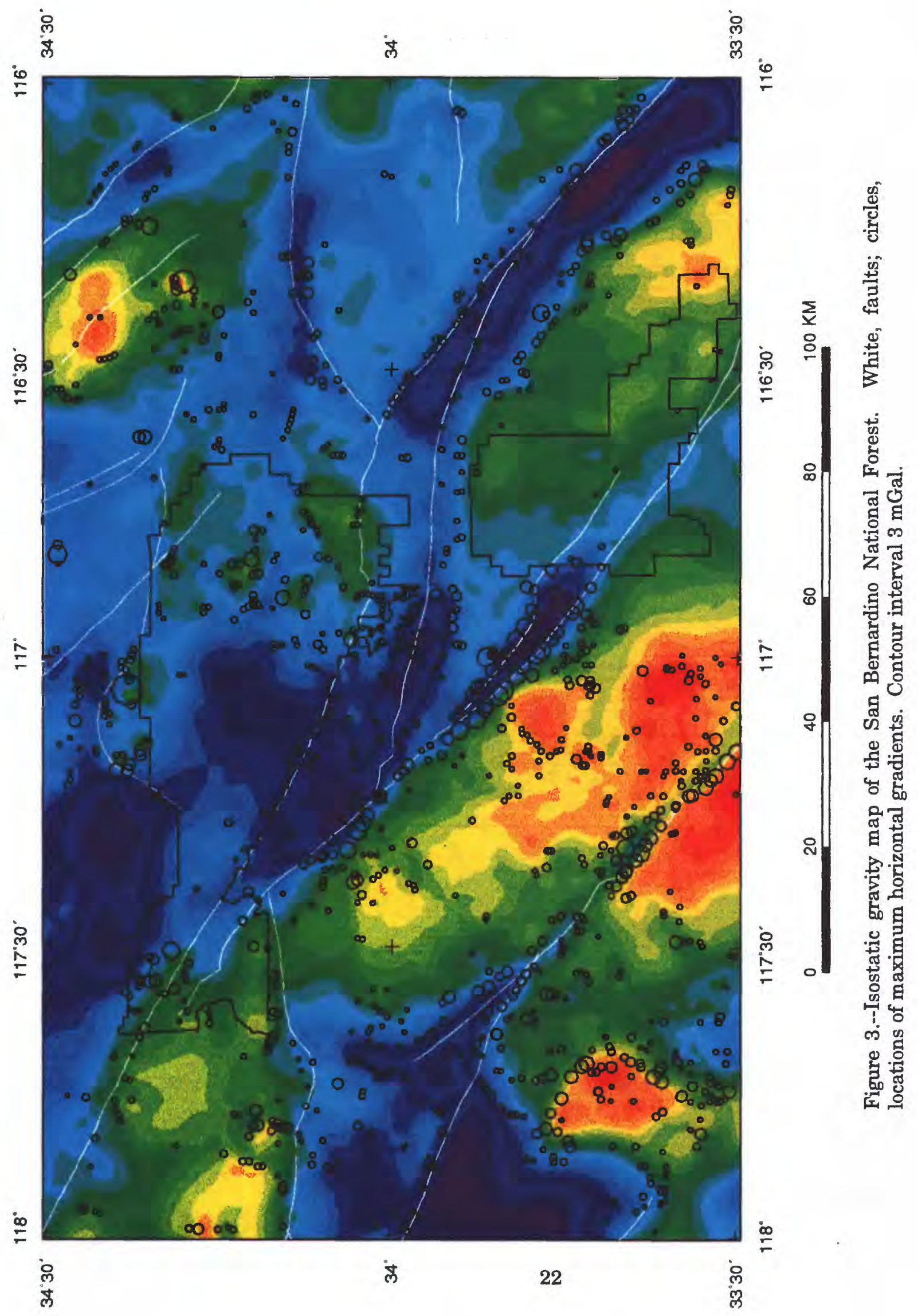




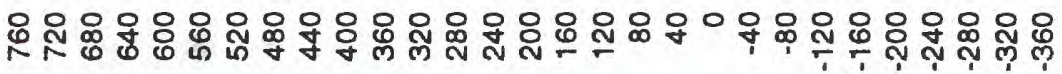
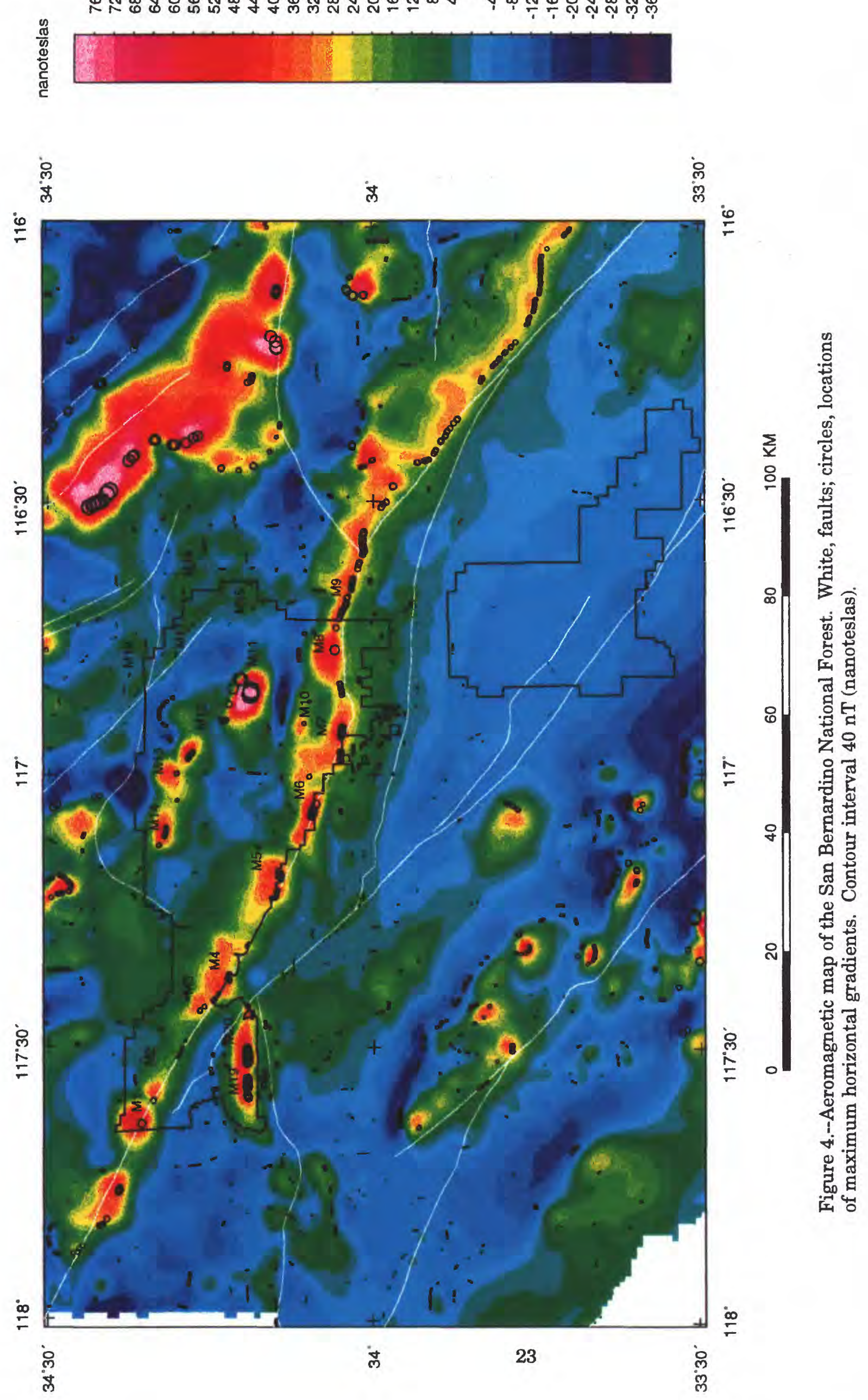


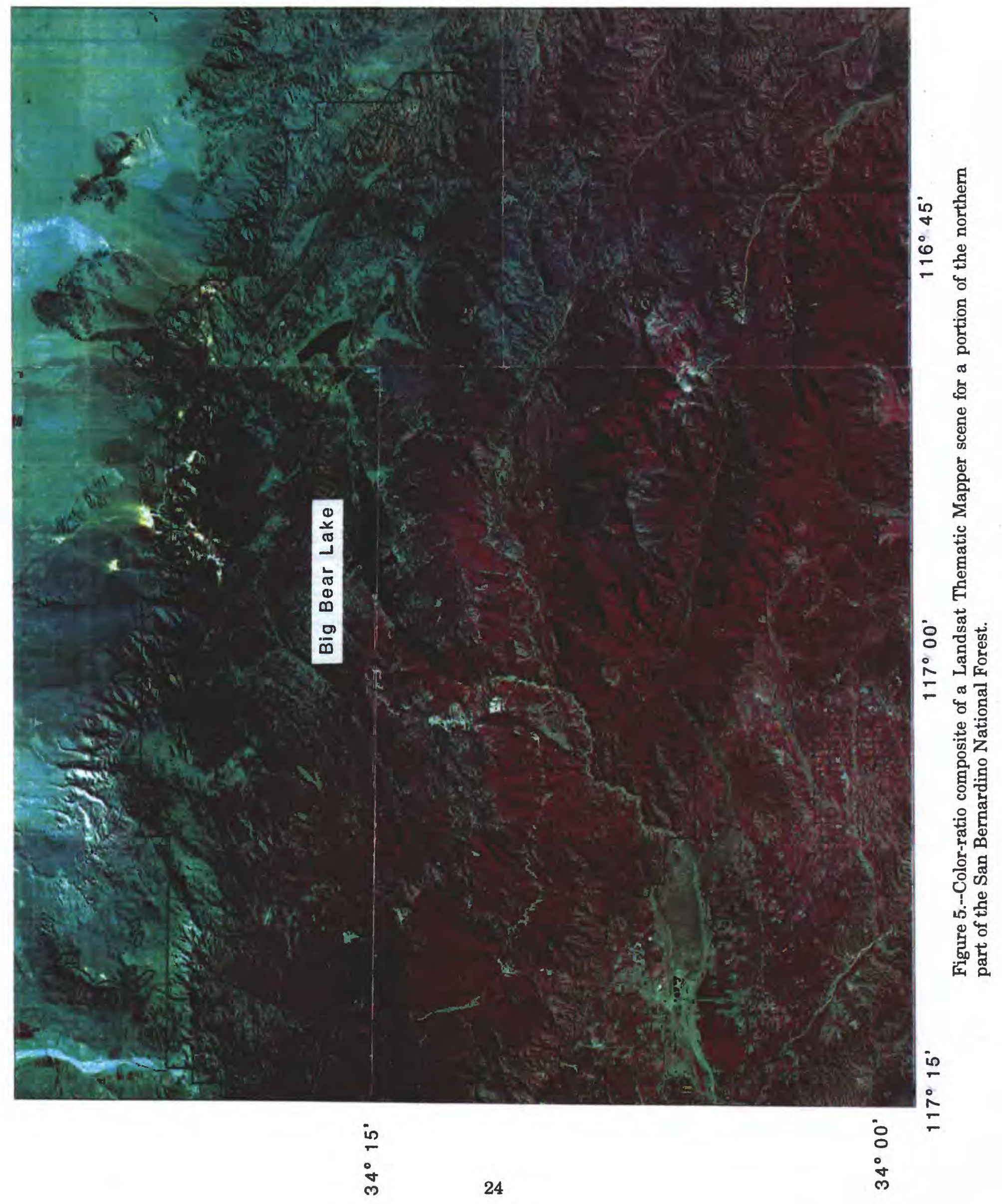




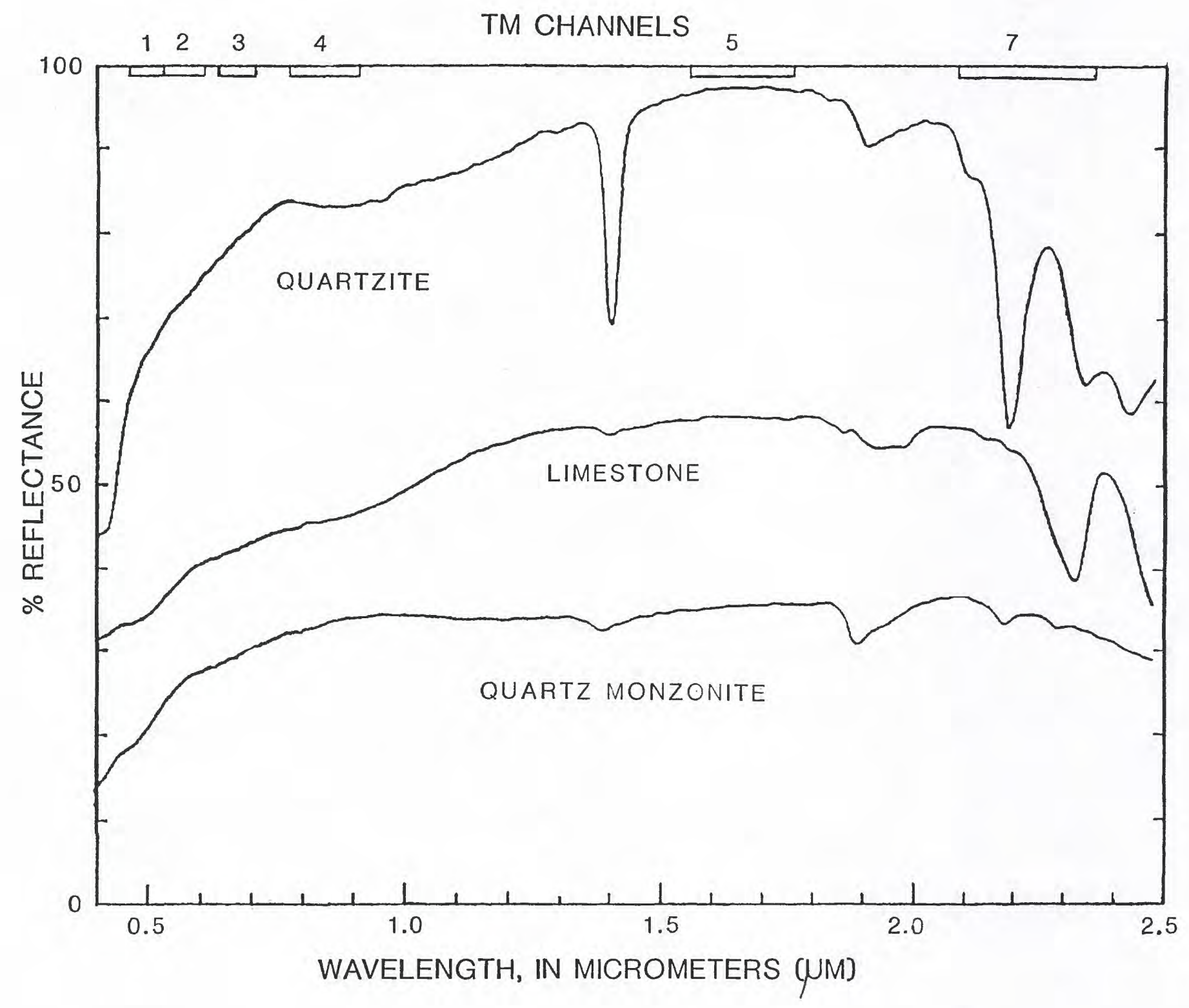

Figure 6.--Laboratory spectral reflectance curves for rocks collected near Mountain Pass, San Bernardino County. Spectra are offset. Band widths of Landsat TM channels are shown at top of figure. 